Article

\title{
Concentration of Mercury in the Livers of Small Terrestrial Rodents from Rural Areas in Poland
}

\author{
Maciej Durkalec ${ }^{1, *}$, , Agnieszka Nawrocka ${ }^{1}$, Jacek Żmudzki ${ }^{2}$, Aleksandra Filipek ${ }^{1}$, \\ Marcin Niemcewicz ${ }^{3}$ and Andrzej Posyniak ${ }^{1}$
}

1 Department of Pharmacology and Toxicology, National Veterinary Research Institute, Aleja Partyzantow 57, 24-100 Puławy, Poland; agnieszka.nawrocka@piwet.pulawy.pl (A.N.);

aleksandra.filipek@piwet.pulawy.pl (A.F.); aposyn@piwet.pulawy.pl (A.P.)

2 Department of Swine Diseases; National Veterinary Research Institute, Aleja Partyzantow 57,

24-100 Puławy, Poland; jaca@piwet.pulawy.pl

3 Biological Threats Identification and Countermeasure Centre, Military Institute of Hygiene and Epidemiology, Lubelska 2, 24-100 Puławy, Poland; marcinniem@wihe.pulawy.pl

* Correspondence: maciej.durkalec@piwet.pulawy.pl; Tel.: +48-81-889-3165

Academic Editors: Giuseppe Scarponi, Silvia Illuminati, Anna Annibaldi and Cristina Truzzi

Received: 17 October 2019; Accepted: 12 November 2019; Published: 14 November 2019

\begin{abstract}
Small terrestrial mammals could be used as accumulative biomonitors of different environmental contaminants, but the knowledge of the level of $\mathrm{Hg}$ in their bodies is scant. The aim of our research was to verify the factors influencing $\mathrm{Hg}$ bioaccumulation and to analyze the concentration of total mercury $(\mathrm{Hg})$ in the livers of four species of wild terrestrial rodents from different rural areas of Poland: the yellow-necked mouse (Apodemus flavicollis), striped field mouse (Apodemus agrarius), common vole (Microtus arvalis), and bank vole (Myodes glareolus). The concentration of total $\mathrm{Hg}$ was analyzed in liver tissue by atomic absorption spectrometry using a direct mercury analyzer. The concentration of $\mathrm{Hg}$ found in the livers of rodents ranged from $<1$ to $36.4 \mu \mathrm{g} / \mathrm{kg}$ of wet weight, differed between study sites, species, and sexes, and was related to body weight. We addressed feeding habits as potential causes of differences in liver $\mathrm{Hg}$ concentration among species.
\end{abstract}

Keywords: total mercury; liver; wild rodents; bank vole; common vole; yellow-necked mouse; striped field mouse

\section{Introduction}

Mercury $(\mathrm{Hg})$ is considered one of the most hazardous non-essential trace elements, and its fate in the environment, where it is ubiquitous, is a matter of concern worldwide [1]. The mechanisms of $\mathrm{Hg}$ toxicity are well known and depend on its chemical form [2,3]. Mercury can be emitted both from natural sources, such as volcanic eruptions and forest fires, and from anthropogenic sources, including coal combustion, notoriously used in the non-ferrous metals industry, cement production, and artisanal gold mining. Global anthropogenic $\mathrm{Hg}$ emissions were estimated at $2220 \mathrm{Mg}$ in 2015 [4]. In Poland, anthropogenic emissions in 2016 were $10.3 \mathrm{Mg}$ and were mainly caused by coal combustion for the production of electricity and heat, in industrial processing of non-ferrous metals, and in small household boilers [5,6]. The deposition of $\mathrm{Hg}$ may lead to contamination of both aquatic and terrestrial ecosystems [1], and inorganic $\mathrm{Hg}$ may be converted by microbial communities into more toxic methylmercury [7], which can be accumulated in the trophic chain [8]. Different organisms have been used as bioindicators of $\mathrm{Hg}$ pollution in terrestrial ecosystems, including invertebrates [9-12], birds [13-15], bats [16], shrews [17-19], moles [19], foxes [20], and mustelids [21,22]. Rodents are also considered good bioindicators of environmental pollution due to their widespread occurrence, high reproductive rate and abundance, short lifespan, and good availability [23,24]. However, differences 
in biotope preferences, feeding habits, and behavior may result in differential bioaccumulation of contaminants between particular species.

The bank vole (Myodes glareolus, Schreber 1780, formerly Clethrionomys glareolus) and the common vole (Microtus arvalis, Pallas 1778) belong to the Arvicolinae subfamily. The bank vole inhabits different types of woodlands [25]. Its diet is based mainly on aerial vegetative parts of plants and fruits but also includes invertebrates and fungi [26]. The common vole has a larger body weight than M. glareolus has $(27.5$ versus $17-20 \mathrm{~g})[27,28]$, prefers open habitats, including meadows, pastures, and farming areas [29], and feeds mainly on herbaceous plants and grasses-invertebrates are very rarely present in its diet [26].

The striped field mouse (Apodemus agrarius, Pallas 1771) and yellow-necked mouse (Apodemus flavicollis, Melchior 1834) are two species that belong to the Muridae family and are also widely distributed in Eurasia, including Poland. The striped field mouse inhabits fields, meadows, gardens, the edges of forests, and roadside scrub parks [30] and is well adapted to urban habitats [31]. Its diet consists mainly of seeds, fruits, and invertebrates [26]. The yellow-necked mouse is considered a typical forest species and rarely occurs in urban areas [31]. The diet of A. flavicollis is more diverse compared to that of $A$. agrarius. Additionally to seeds, fruits, and invertebrates, A. flavicollis eats aboveground parts of plants, flowers, and fungi [26].

The objectives of our work were to analyze the concentration of total $\mathrm{Hg}$ in the livers of these four species of rodents and to verify the influence of study site, age, sex, and body weight (b.w.) on $\mathrm{Hg}$ bioaccumulation.

\section{Results}

The concentration of $\mathrm{Hg}$ found in the livers of rodents ranged from $<1$ to $36.4 \mu \mathrm{g} / \mathrm{kg}$ wet weight. The descriptive statistics of $\mathrm{Hg}$ concentrations in the livers of rodents according to their species, sex, and sampling site are summarized in Supplementary Table S3. Generalized linear model (GLM) analysis showed that liver $\mathrm{Hg}$ concentrations were influenced by study site $\left(\mathrm{F}=10.1, p=2 \times 10^{-16}\right)$, $\operatorname{sex}\left(\mathrm{F}=9.9, p=1.9 \times 10^{-3}\right)$, species $\left(\mathrm{F}=6.1, p=5.6 \times 10^{-4}\right)$, and body weight $\left(\mathrm{F}=7.7, p=5.9 \times 10^{-3}\right)$. Site-specific differences in liver $\mathrm{Hg}$ concentrations are shown in Figure 1. The highest estimated mean level of $\mathrm{Hg}$ in the livers of all species of rodents was at the DAB site $(15 \pm 4 \mu \mathrm{g} / \mathrm{kg})$ and was higher than that found in other study sites $(p<0.05)$, with the exception of GLW and SWI. The second area with high liver $\mathrm{Hg}$ concentration was GLW $(7.9 \pm 2 \mu \mathrm{g} / \mathrm{kg})$, located in Upper Silesia, and animals from STA had the lowest marginal mean $\mathrm{Hg}$ content in the liver $(1.5 \mu \mathrm{g} / \mathrm{kg})$. Differences between estimated marginal mean concentrations of $\mathrm{Hg}$ among study sites are presented in Supplementary Table $\mathrm{S} 4$ for clarification. Some differences between species were also salient. The levels of $\mathrm{Hg}$ in the livers of A. flavicollis were about half those of A. agrarius and M. arvalis (Figure 2A). The estimated mean $\mathrm{Hg}$ level in the livers of $M$. glareolus was $4.7 \pm 2 \mu \mathrm{g} / \mathrm{kg}$, which was almost twice that of A. flavicollis, but the difference was not confirmed statistically. Comparing the differences between sexes, it was found that males tended to accumulate about 38\% more $\mathrm{Hg}$ in their livers than females (Figure 2B). Rodent body weight and $\mathrm{Hg}$ concentration in the liver were positively correlated, as shown by the Spearman rank correlation test (Figure 3), which confirmed the GLM findings. 


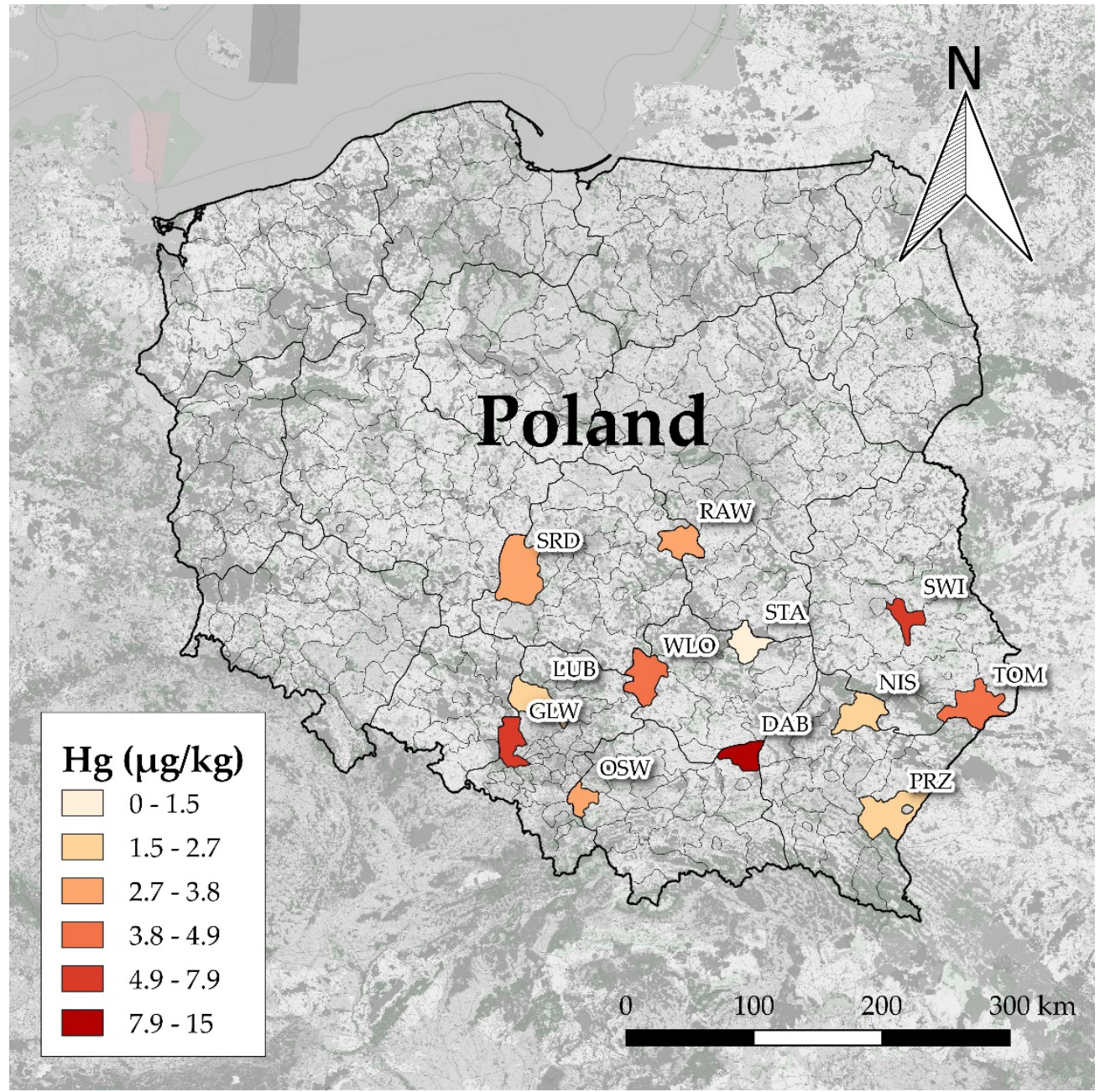

Figure 1. Concentrations of $\mathrm{Hg}$ in the livers of rodents from 12 study sites. The color scale represents estimated marginal means (in $\mu \mathrm{g} / \mathrm{kg}$ of wet weight.). Results were averaged by species and sex.
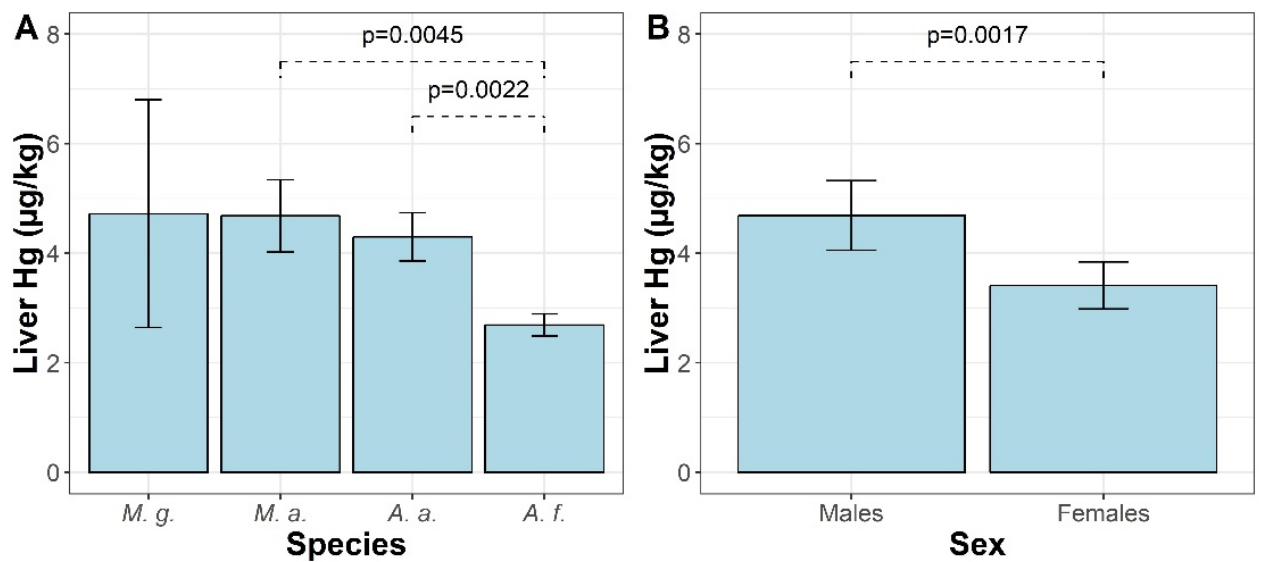

Figure 2. (A) Differences in Hg concentrations in the liver between species (M. g-Myodes glareolus; M. a.-Microtus arvalis; A. a.-Apodemus agrarius; A. f.-Apodemus flavicollis). Results (in $\mu \mathrm{g} / \mathrm{kg}$ of wet weight) were averaged by study site and sex. (B) Differences in $\mathrm{Hg}$ concentrations in the liver between males and females (in $\mu \mathrm{g} / \mathrm{kg}$ of wet weight). Results were averaged by study site and species. Both bar and whisker plots show estimated marginal means and standard errors that were back-transformed from the log scale. Differences between marginal means were verified on the log scale. 


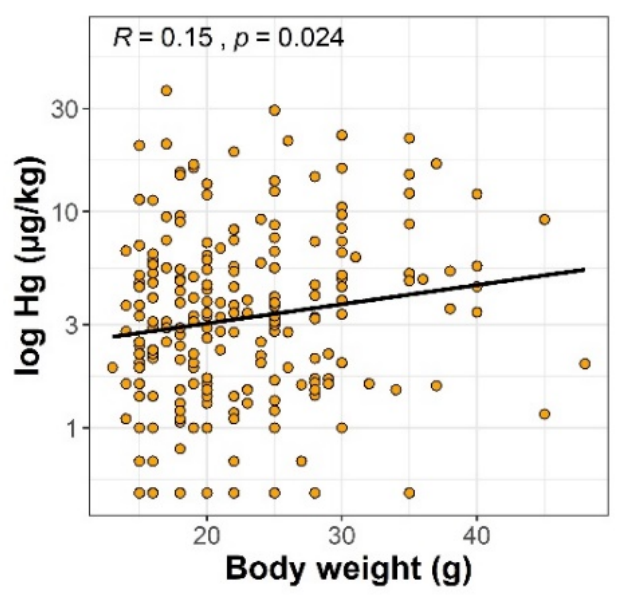

Figure 3. Spearman rank correlation coefficients between body weight of rodents and concentrations of $\mathrm{Hg}$ in their livers.

\section{Discussion}

We found the highest levels of $\mathrm{Hg}$ in rodents from the DAB and GLW areas. The DAB area is located in the northeastern part of the Małopolskie voivodeship. According to national monitoring data, the median background $\mathrm{Hg}$ level in topsoil collected at the DAB site was $0.090 \mathrm{mg} / \mathrm{kg}$ (Supplementary Table S1). Surprisingly, there were no known major emitters close to the area, such as power plants, smelters, or other heavy industrial facilities, that may have been a source of $\mathrm{Hg}$ to the surrounding environment. We assume that local emissions caused by the combustion of coal in household boilers could also contribute to $\mathrm{Hg}$ bioaccumulation in biota [32]. The second region to the DAB site in terms of $\mathrm{Hg}$ content in the livers of rodents was located in the western part of the Upper Silesian Industrial District, which is known as one of the most polluted parts of Poland and is mainly associated with coal mining and metal production. Mercury levels in this area could be three- to sixfold higher than in rural areas in Poland [33], which our findings confirm.

The mean concentration of $\mathrm{Hg}$ found in the livers of all species of rodents from the most polluted DAB site (15 $\mu \mathrm{g} / \mathrm{kg}$ of wet weight) was one-seventh of the level of $\mathrm{Hg}$ found in the livers of A. flavicollis from areas polluted by lead smelting in Slovenia, but threefold higher than that observed in the same species captured in the area contaminated by power plant emissions in that country [34]. Much higher levels than ours were found in Microtus guentheri from the marble mining area in Turkey [35], in $M$. glareolus from the zone around a chlor-alkali plant in Great Britain [36], and in Apodemus sylvaticus from different polluted and unpolluted areas in Galicia in northern Spain [37]. However, threefold lower $\mathrm{Hg}$ levels were noted in M. glareolus inhabiting the area affected by metal-processing industry in Russia [18]. Literature data on Hg levels in the livers of wild rodents are summarized in Table 1.

Mercury can accumulate along the trophic gradient in food webs, and the level of this element increases with the higher trophic position of animals $[3,18]$. However, the bioaccumulation of $\mathrm{Hg}$ may depend on dietary protein level and glutathione metabolism [38] and on the role of gut microbiota in demethylation and excretion of $\mathrm{Hg}$ [39]. The lowest liver $\mathrm{Hg}$ levels were found in A. flavicollis. Our results are in line with the results of Martiniaková et al. [40], who found that A. flavicollis was a biomonitor with lower metal concentration than M. glareolus. Mice of the Apodemus species have a more variable and protein-rich diet than herbivorous voles [41], and the richness of diet may result in lower bioaccumulation of toxic elements due to "diet dilution" [42]. We hypothesize that mycophagy could be another explanation for species-specific differences in liver $\mathrm{Hg}$ concentration in rodents. Fungi can accumulate $\mathrm{Hg}$ from the environment, and $\mathrm{Hg}$ levels in fruiting bodies could be higher than $4 \mathrm{mg} / \mathrm{kg}$ of dry weight [43-45]. In our study, all rodents were captured from early summer to the end of October, when fungi were readily available. Blaschke and Bäumler reported that fungal spores can account for $7 \%$ of the stomach volume of A. flavicollis and up to $36 \%$ of the stomach content 
of M. glareolus [46]. Besides species-specific feeding habits, the frequency of mycophagy in rodents also depends on the availability of this dietary component during the year. The analysis of fungal spores in fresh fecal pellets of rodents showed that they were present in almost $100 \%$ of examined individuals of M. glareolus during summer and autumn, whereas in Apodemus spp., only $30-40 \%$ of individuals consumed fungi during summer, although the frequency increased to approximately $80 \%$ in autumn [47]. The bioaccumulation of $\mathrm{Hg}$ may be different between the sexes. Lower levels of $\mathrm{Hg}$ in female mammals may be due to depuration during lactation [48].

Table 1. Concentrations of $\mathrm{Hg}$ in the livers of small terrestrial mammals from different areas (in $\mu \mathrm{g} / \mathrm{kg}$ of wet weight).

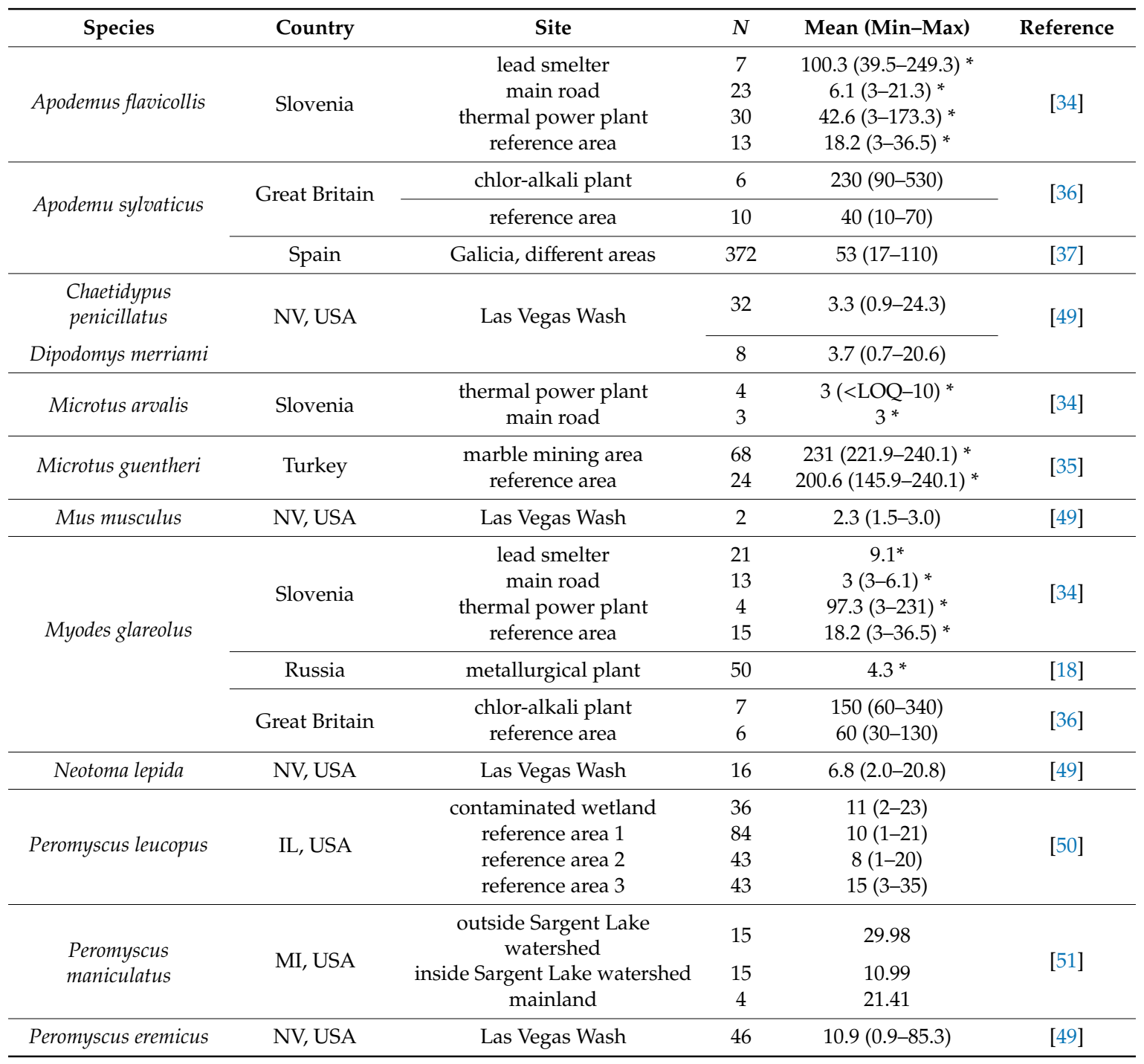

* Results calculated from original data given on dry wt. basis assuming $30.4 \%$ of solids.

The higher Hg concentrations in the livers of rodents found in our study corroborate the results reported by Sánchez-Chardi in white-toothed shrews (Crocidura russula) [52]. We are aware that the lack of the ages of the rodents, whch were not recorded during the study, is a limitation of our research. The estimation of the age of rodents by body size could be imprecise because different factors affect their growth [53]. Nevertheless, we found a positive correlation between body weight and liver $\mathrm{Hg}$ in rodents, which could be explained by the accumulation of $\mathrm{Hg}$ within their lifespan. Our study showed that the concentration of $\mathrm{Hg}$ in the liver of wild rodents may depend on different factors, including the level of exposure in their habitat, species, sex, and b.w. We suspect that differences in liver $\mathrm{Hg}$ 
concentrations between species of rodents may be caused by feeding habits, and future studies are needed to investigate the potential sources of $\mathrm{Hg}$ in their diet.

\section{Materials and Methods}

\subsection{Sampling}

A total of 221 free-living small rodents were captured between June 2016 and October 2017 in 12 study sites (counties) of central, southeastern, and eastern Poland. The characteristics of all study sites, including mean annual temperature, annual rainfall, altitude, type of vegetation, and background soil $\mathrm{Hg}$, and the number of animals sampled per species and sex are summarized in Supplementary Table S1. All animals were caught by a standard live-trapping technique in their natural foraging areas located close to farm buildings, using Sherman traps with baits of cereal grain and fresh apple. Four species of wild rodents were chosen: the bank vole (M. glareolus), common vole (M. arvalis), striped field mouse (A. agrarius), and yellow-necked mouse (A. flavicollis). Live animals were transported to the laboratory and euthanized, and necropsies were performed in a laminar chamber on the same day as capture. Liver samples were taken using stainless-steel surgical scissors, placed in $1.5 \mathrm{~mL}$ Eppendorf tubes, and frozen at $-20^{\circ} \mathrm{C}$ until analysis. The sampling of rodents was performed within a project that was focused on small mammals as sentinels for multiple zoonotic pathogens and was approved by the Local Ethics Committee for Animal Experimentation in Lublin under Resolution No. 30/2016. No ethical committee permission was required for the analysis of $\mathrm{Hg}$, as the samples were taken post-mortem for this purpose.

\subsection{Mercury Analysis}

Frozen samples were thawed at $4{ }^{\circ} \mathrm{C}$. The analysis of $\mathrm{Hg}$ in liver tissue was performed in raw tissue by a previously described method [54] using a Tri-cell DMA-80 ${ }^{\circledR}$ direct mercury analyzer (Milestone Srl, Sorisole (BG), Italy). Quantification of Hg was based on external calibration curves in three independent working ranges. Standard solutions (from 3 to 30, from 3 to 150, and from 250 to 10,000 $\mathrm{gg} / \mathrm{L}$ ) were prepared by dilution of an $\mathrm{Hg}$ standard stock solution (J.T. Baker, $1000 \mathrm{mg} / \mathrm{L})$ (Avantor Performance Materials B.V, Deventer, the Netherlands) with 1\% (v/v) nitric acid (Suprapur ${ }^{\circledR}$, Merck, Darmstadt, Germany). Briefly, using an ENTRIS 2241-1S analytical balance (Sartorius Lab Instruments $\mathrm{GmbH} \& \mathrm{Co}$, Goettingen, Germany) approximately $50 \pm 0.1 \mathrm{mg}$ of liver tissue was weighed into nickel boats and placed on the autosampler rotor of the DMA-80. The analysis took 5.5 min per sample. The operating conditions are shown in Supplementary Table S2. Quality control of the measurements was provided by using the following certified reference materials (CRMs): SRM-1577c Bovine Liver (National Institute of Standards and Technology (NIST), Gaithersburg, MD, USA), Chicken ZC73016 (NCS Testing Technology Co., Beijing, China), and MODAS-3 Herring tissue (M-3 HerTis) (Institute of Nuclear and Technology (IChTJ), Warsaw, Poland). Recoveries of Hg in CRMs were 98\%, 122\%, and 97\% for SRM-1577c, ZC73016, and M-3 HerTis, respectively. The limit of quantification of the method was $1 \mu \mathrm{g} / \mathrm{kg}$ of wet weight. The method is accredited according to ISO/IEC 17025/Ap1:2007 [55] and regularly verified in proficiency tests organized by the European Union Reference Laboratory for Metals and Nitrogenous Compounds in Feed and Food (EURL-MN) in Lyngby, Denmark.

We also measured the moisture content in the livers of rodents to facilitate the comparison of our results with literature data. The moisture content was analyzed in 16 randomly selected subsamples of the liver using an HR83 moisture analyzer (Mettler Toledo, Switzerland) according to the manufacturer's instructions. The mean content of dry matter in the liver of rodents was 30.4\%, and this level was used for calculations. All of the results in this article are expressed in $\mu \mathrm{g} / \mathrm{kg}$ of wet weight. 


\subsection{Statistical Analysis}

Statistical analysis was performed using $\mathrm{R}$ in version 3.6.0 [56]. The data handling and descriptive statistics calculation, including mean, standard deviation, median, median absolute deviation (MAD), and range were performed in the dplyr package, version 0.8.1 [57]. Results below LOQ were set as 0.5 of the LOQ. The Shapiro-Wilk normality test was used to verify the normality of distribution [58], and because data were not normally distributed, we used log-transformation to achieve the normality. Effects of species, study site, sex, season of sampling (summer and autumn), feeding habits (omnivores and herbivores), and body weight were verified using GLM [59]. We constructed GLM with Gaussian distribution as follows: log-transformed $\mathrm{Hg}$ concentration was used as the dependent variable, and all factors (species, study site, sex, season of sampling, feeding habit, and body weight) were used as predictors. The best model was chosen by the step command with forward-backward stepwise procedure based on Akaïke's Information Criterion (AIC). Differences between factor levels were verified by post-hoc tests with Bonferroni adjustment of $p$-values on estimated marginal means using version 1.4.1 of the emmeans package [60]. The Spearman's rank correlation coefficient was used to verify the relationship between $\mathrm{Hg}$ accumulation in the liver and the b.w. The results were visualized using the ggplot2 package (version 3.2.1) [61], and the map with estimated marginal mean concentrations of $\mathrm{Hg}$ in the livers of rodents in selected study sites was plotted by QGIS software version 3.8 [62].

Supplementary Materials: The following are available online. Supplementary Table S1 of the characteristics of study sites and the number of rodents captured according to study site, species, and sex; Supplementary Table S2 of the DMA-80 operating conditions; Supplementary Table S3 of the descriptive statistics of $\mathrm{Hg}$ concentrations in the liver of rodents according to their species, sampling site, and sex $(\mu \mathrm{g} / \mathrm{kg})$; Supplementary Table S4 of the differences in liver Hg concentrations in rodents between study sites; Supplementary Table S5 of the differences in liver $\mathrm{Hg}$ concentrations in rodents between species; and Supplementary Table S6 of the differences in liver $\mathrm{Hg}$ concentrations in rodents between females and males.

Author Contributions: Conceptualization, M.D. and A.N.; methodology, A.N.; formal analysis, M.D.; investigation, M.D. and A.F.; resources, M.N. and J.Ż.; supervising, A.P; writing-original draft preparation, M.D. and A.N; writing—review and editing, A.P., M.N., and J.Ż.; visualization, M.D.; funding acquisition, J.Ż. and M.D.

Funding: This research was funded by the KNOW (Leading National Research Centre) Scientific Consortium "Healthy Animal-Safe Food", decision of Ministry of Science and Higher Education Resolution No. 05-1/KNOW2/2015, and sampling was supported by the National Science Centre, Krakow, Poland, grant number DEC-2013/09/B/NZ7/02563.

Acknowledgments: We express our gratitude to Scott Carter for English proofreading.

Conflicts of Interest: The authors declare no conflict of interest.

\section{References}

1. Driscoll, C.T.; Mason, R.P.; Chan, H.M.; Jacob, D.J;; Pirrone, N. Mercury as a Global Pollutant: Sources, Pathways, and Effects. Environ. Sci. Technol. 2013, 47, 4967-4983. [CrossRef] [PubMed]

2. Clarkson, T.W.; Magos, L. The toxicology of mercury and its chemical compounds. Crit. Rev. Toxicol. 2006, 36, 609-662. [CrossRef] [PubMed]

3. Boening, D.W. Ecological effects, transport, and fate of mercury: A general review. Chemosphere 2000, 40, 1335-1351. [CrossRef]

4. UN Environment. Global Mercury Assessment 2018; UN Environment Programme Economy Division Chemicals and Health Branch International Environment House: Geneva, Switzerland, 2019; pp. 1-62.

5. KOBiZE. Poland's Informative Inventory Rreport 2018. Submission under the UN ECE Convention on Long-Range Transboundary Air Pollution and the DIRECTIVE (EU) 2016/2284; National Centre for Emission Management (KOBiZE) at the Institute of Environmental Protection-National Research Institute: Warsaw, Poland, 2018; pp. 1-286.

6. Pyka, I.; Wierzchowski, K. Estimated mercury emissions from coal combustion in the households sector in Poland. J. Sustain. Min. 2016, 15, 66-72. [CrossRef] 
7. Xu, J.; Buck, M.; Eklöf, K.; Ahmed, O.O.; Schaefer, J.K.; Bishop, K.; Skyllberg, U.; Björn, E.; Bertilsson, S.; Bravo, A.G. Mercury methylating microbial communities of boreal forest soils. Sci. Rep. 2019, 9, 1-13. [CrossRef] [PubMed]

8. Tsz-Ki Tsui, M.; Liu, S.; Brasso, R.L.; Blum, J.D.; Kwon, S.Y.; Ulus, Y.; Nollet, Y.H.; Balogh, S.J.; Eggert, S.L.; Finlay, J.C. Controls of Methylmercury Bioaccumulation in Forest Floor Food Webs. Environ. Sci. Technol. 2019, 53, 2434-2440. [CrossRef]

9. Rodríguez Álvarez, C.; Jiménez-Moreno, M.; Guzmán Bernardo, F.J.; Rodríguez Martín-Doimeadios, R.C.; Berzas Nevado, J.J. Using species-specific enriched stable isotopes to study the effect of fresh mercury inputs in soil-earthworm systems. Ecotoxicol. Environ. Saf. 2018, 147, 192-199. [CrossRef]

10. Abeysinghe, K.S.; Yang, X.-D.; Goodale, E.; Anderson, C.W.N.; Bishop, K.; Cao, A.; Feng, X.; Liu, S.; Mammides, C.; Meng, B.; et al. Total mercury and methylmercury concentrations over a gradient of contamination in earthworms living in rice paddy soil. Environ. Toxicol. Chem. 2017, 36, 1202-1210. [CrossRef]

11. Ortiz, C.; Weiss-Penzias, P.S.; Fork, S.; Flegal, A.R. Total and Monomethyl Mercury in Terrestrial Arthropods from the Central California Coast. Bull. Environ. Contam. Toxicol. 2015, 94, 425-430. [CrossRef]

12. Zheng, D.; Liu, X.; Jin, D.; Li, H.; Li, X. Mercury bioaccumulation in arthropods from typical community habitats in a zinc-smelting area. Environ. Geochem. Health 2018, 40, 1329-1337. [CrossRef]

13. Janiga, M.; Haas, M. Alpine accentors as monitors of atmospheric long-range lead and mercury pollution in alpine environments. Environ. Sci. Pollut. Res. 2019, 26, 2445-2454. [CrossRef] [PubMed]

14. Jackson, A.K.; Evers, D.C.; Adams, E.M.; Cristol, D.A.; Eagles-Smith, C.; Edmonds, S.T.; Gray, C.E.; Hoskins, B.; Lane, O.P.; Sauer, A.; et al. Songbirds as sentinels of mercury in terrestrial habitats of eastern North America. Ecotoxicology 2015, 24, 453-467. [CrossRef] [PubMed]

15. Costa, R.A.; Eeva, T.; Eira, C.; Vaqueiro, J.; Vingada, J.V. Assessing heavy metal pollution using Great Tits (Parus major): Feathers and excrements from nestlings and adults. Environ. Monit. Assess. 2013, 185, 5339-5344. [CrossRef] [PubMed]

16. Korstian, J.M.; Chumchal, M.M.; Bennett, V.J.; Hale, A.M. Mercury contamination in bats from the central United States. Environ. Toxicol. Chem. 2018, 37, 160-165. [CrossRef]

17. Sánchez-Chardi, A.; López-Fuster, M.J.; Nadal, J. Bioaccumulation of lead, mercury, and cadmium in the greater white-toothed shrew, Crocidura russula, from the Ebro Delta (NE Spain): Sex- and age-dependent variation. Environ. Pollut. 2007, 145, 7-14. [CrossRef]

18. Komov, V.T.; Ivanova, E.S.; Poddubnaya, N.Y.; Gremyachikh, V.A. Mercury in soil, earthworms and organs of voles Myodes glareolus and shrew Sorex araneus in the vicinity of an industrial complex in Northwest Russia (Cherepovets). Environ. Monit. Assess. 2017, 189, 104. [CrossRef]

19. Antonova, E.P.; Ilyukha, V.A.; Komov, V.T.; Khizhkin, E.A.; Sergina, S.N.; Gremyachikh, V.A.; Kamshilova, T.B.; Belkin, V.V.; Yakimova, A.E. The Mercury Content and Antioxidant System in Insectivorous Animals (Insectivora, Mammalia) and Rodents (Rodentia, Mammalia) of Various Ecogenesis Conditions. Biol. Bull. 2017, 44, 1272-1277. [CrossRef]

20. Kalisinska, E.; Lisowski, P.; Kosik-Bogacka, D.I. Red Fox Vulpes vulpes (L, 1758) as a Bioindicator of Mercury Contamination in Terrestrial Ecosystems of North-Western Poland. Biol. Trace Elem. Res. 2012, 145, 172-180. [CrossRef]

21. Kalisinska, E.; Lisowski, P.; Salicki, W.; Kucharska, T.; Kavetska, K. Mercury in wild terrestrial carnivorous mammals from north-western Poland and unusual fish diet of red fox. Acta Theriol. 2009, 54, 345-356. [CrossRef]

22. Kalisińska, E.; Łanocha-Arendarczyk, N.; Kosik-Bogacka, D.I. Mercury, Hg. In Mammals and Birds as Bioindicators of Trace Element Contaminations in Terrestrial Environments; Springer International Publishing: Cham, Switzerland, 2019; pp. 593-653.

23. Wren, C.D. Mammals as biological monitors of environmental metal levels. Environ. Monit. Assess. 1986, 6, 127-144. [CrossRef]

24. Talmage, S.S.; Walton, B.T. Small mammals as monitors of environmental contaminants. Rev. Environ. Contam. Toxicol. 1991, 119, 47-145. [PubMed]

25. Mazurkiewicz, M. Factors influencing the distribution of the bank vole in forest habitats. Acta Theriol. 1994, 39, 113-126. [CrossRef] 
26. Butet, A.; Delettre, Y.R. Diet differentiation between European arvicoline and murine rodents. Acta Theriol. 2011, 56, 297. [CrossRef]

27. Lundrigan, B.; Mueller, M. Myodes glareolus (On-line), Animal Diversity Web. Available online: https: //animaldiversity.org/site/accounts/information/Myodes_glareolus.html (accessed on 1 October 2019).

28. Noble, S. "Microtus arvalis" (On-line), Animal Diversity Web. Available online: https://animaldiversity.org/ accounts/Microtus_arvalis/ (accessed on 1 October 2019).

29. Jacob, J.; Manson, P.; Barfknecht, R.; Fredricks, T. Common vole (Microtus arvalis) ecology and management: Implications for risk assessment of plant protection products. Pest Manag. Sci. 2014, 70, 869-878. [CrossRef]

30. Kowalski, K.; Pucek, Z.; Ruprecht, A.L. Rząd: Gryzonie-Rodentia. In Klucz do Oznaczania Ssaków Polski; Pucek, Z., Ed.; PWN: Warsaw, Poland, 1984; pp. 149-240.

31. Gortat, T.; Barkowska, M.; Gryczyńska-Siemiątkowska, A.; Pieniążek, A.; Kozakiewicz, A.; Kozakiewicz, M. The Effects of Urbanization-Small Mammal Communities in a Gradient of Human Pressure in Warsaw City, Poland. Polish J. Ecol. 2014, 62, 163-172. [CrossRef]

32. Zielonka, U.; Hlawiczka, S.; Fudala, J.; Wängberg, I.; Munthe, J. Seasonal mercury concentrations measured in rural air in Southern Poland: Contribution from local and regional coal combustion. Atmos. Environ. 2005, 39, 7580-7586. [CrossRef]

33. Pyta, H.; Rosik-Dulewska, C.; Czaplicka, M. Speciation of Ambient Mercury in the Upper Silesia Region, Poland. Water. Air. Soil Pollut. 2009, 197, 233-240. [CrossRef]

34. Al Sayegh Petkovšek, S.; Kopušar, N.; Kryštufek, B. Small mammals as biomonitors of metal pollution: A case study in Slovenia. Environ. Monit. Assess. 2014, 186, 4261-4274. [CrossRef]

35. Yavuz, M.; Aktas, O. Heavy metal accumulation in the Microtus guentheri (Danford and Alston, 1880) living near the mines as biomonitor. Fresenius Environ. Bull. 2017, 26, 1104-1121.

36. Bull, K.R.; Roberts, R.D.; Inskip, M.J.; Goodman, G.T. Mercury concentrations in soil, grass, earthworms and small mammals near an industrial emission source. Environ. Pollut. 1977, 12, 135-140. [CrossRef]

37. Ángel Fernández, J.; Aboal, J.R.; González, X.I.; Carballeira, A. Transfer and bioaccumulation variability of $\mathrm{Cd}, \mathrm{Co}, \mathrm{Cr}, \mathrm{Hg}, \mathrm{Ni}$ and $\mathrm{Pb}$ in trophic compartments of terrestrial ecosystems in Northern Spain. Fresenius Environ. Bull. 2012, 21, 3527-3532.

38. Adachi, T.; Yasutake, A.; Eto, K.; Hirayama, K. Influence of dietary protein levels on the acute toxicity of methylmercury in mice. Toxicology 1996, 112, 11-17. [CrossRef]

39. Rowland, I.R.; Robinson, R.D.; Doherty, R.A. Effects of diet on mercury metabolism and excretion in mice given methylmercury: Role of gut Flora. Arch. Environ. Health 1984, 39, 401-408. [CrossRef] [PubMed]

40. Martiniaková, M.; Omelka, R.; Grosskopf, B.; Jančová, A. Yellow-necked mice (Apodemus flavicollis) and bank voles (Myodes glareolus) as zoomonitors of environmental contamination at a polluted area in Slovakia. Acta Vet. Scand. 2010, 52, 58. [CrossRef]

41. Čepelka, L.; Heroldová, M.; Jánová, E.; Suchomel, J. The dynamics of nitrogenous substances in rodent diet in a forest environment. Mammalia 2014, 78, 327-333. [CrossRef]

42. Ozaki, S.; Fritsch, C.; Valot, B.; Mora, F.; Cornier, T.; Scheifler, R.; Raoul, F. How Do Richness and Composition of Diet Shape Trace Metal Exposure in a Free-Living Generalist Rodent, Apodemus sylvaticus. Environ. Sci. Technol. 2019, 53, 5977-5986. [CrossRef]

43. Falandysz, J.; Krasińska, G.; Pankavec, S.; Nnorom, I.C. Mercury in certain boletus mushrooms from Poland and Belarus. J. Environ. Sci. Health B 2014, 49, 690-695. [CrossRef]

44. Falandysz, J.; Szymczyk, K.; Ichihashi, H.; Bielawski, L.; Gucia, M.; Frankowska, A.; Yamasaki, S.I. ICP/MS and ICP/AES elemental analysis (38 elements) of edible wild mushrooms growing in Poland. Food Addit. Contam. 2010, 18, 503-513. [CrossRef]

45. Rieder, S.R.; Brunner, I.; Horvat, M.; Jacobs, A.; Frey, B. Accumulation of mercury and methylmercury by mushrooms and earthworms from forest soils. Environ. Pollut. 2011, 159, 2861-2869. [CrossRef]

46. Blaschke, H.; Bäumler, W. Mycophagy and spore dispersal by small mammals in bavarian forests. For. Ecol. Manag. 1989, 26, 237-245. [CrossRef]

47. Kataržytė, M.; Kutorga, E. Small mammal mycophagy in hemiboreal forest communities of Lithuania. Cent. Eur. J. Biol. 2011, 6, 446-456. [CrossRef]

48. Wada, H.; Yates, D.E.; Evers, D.C.; Taylor, R.J.; Hopkins, W.A. Tissue mercury concentrations and adrenocortical responses of female big brown bats (Eptesicus fuscus) near a contaminated river. Ecotoxicology 2010, 19, 1277-1284. [CrossRef] [PubMed] 
49. Gerstenberger, S.L.; Cross, C.L.; Divine, D.D.; Gulmatico, M.L.; Rothweiler, A.M. Assessment of mercury concentrations in small mammals collected near Las Vegas, Nevada, USA. Environ. Toxicol. 2006, 21, 583-589. [CrossRef]

50. Levengood, J.M.; Heske, E.J. Heavy metal exposure, reproductive activity, and demographic patterns in white-footed mice (Peromyscus leucopus) inhabiting a contaminated floodplain wetland. Sci. Total Environ. 2008, 389, 320-328. [CrossRef]

51. Vucetich, L.; Vucetich, J.; Cleckner, L.; Gorski, P.; Peterson, R. Mercury concentrations in deer mouse (Peromyscus maniculatus) tissues from Isle Royale National Park. Environ. Pollut. 2001, 114, 113-118. [CrossRef]

52. Sánchez-Chardi, A.; López-Fuster, M.J. Metal and metalloid accumulation in shrews (Soricomorpha, Mammalia) from two protected Mediterranean coastal sites. Environ. Pollut. 2009, 157, 1243-1248. [CrossRef]

53. Adamczewska-Andrzejewska, K.A. Methods of age determination in Apodemus agrarius (Pallas 1771). Ann. Zool. Fenn. 1971, 8, 68-71.

54. Szkoda, J.; Zmudzki, J.; Grzebalska, A. Determination of total mercury in biological material by atomic absorption spectrometry method. Bull. Vet. Inst. Pulawy 2006, 50, 363-366.

55. International Standard Organization ISO/IEC 17025 General requirements for the competence of testing and calibration laboratories. Int. Stand. 2005, 2005, 1-36.

56. R Core Team. R: A Language and Environment for Statistical Computing. Version 3.6.0. Available online: http://www.r-project.org/ (accessed on 1 October 2019).

57. Wickham, H.; Romain, F.; Lionel, H.; Müller, K. dplyr: A Grammar of Data Manipulation. R Package Version 0.8.1. Available online: https://cran.r-project.org/package=dplyr (accessed on 1 October 2019).

58. Yap, B.W.; Sim, C.H. Comparisons of various types of normality tests. J. Stat. Comput. Simul. 2011, 81, 2141-2155. [CrossRef]

59. Zuur, A.F.; Ieno, E.N.; Walker, N.; Saveliev, A.A.; Smith, G.M. Mixed Effects Models and Extensions in Ecology with R; Krämer, A., Kretzschmar, M., Krickeberg, K., Eds.; Statistics for Biology and Health; Springer: New York, NY, USA, 2009; pp. 1-574.

60. Lenth, R. emmeans: Estimated Marginal Means, aka Least-Squares Means. R Package Version 1.4.1. Available online: https://cran.r-project.org/package=emmeans (accessed on 1 October 2019).

61. Wickham, H. ggplot2: Elegant Graphics for Data Analysis, 2nd ed.; Springer: New York, NY, USA, 2016; pp. 1-260.

62. Team, Q.D. QGIS Geographic Information System. Open Source Geospatial Foundation Project. Version 3.8. Available online: http://qgis.osgeo.org/ (accessed on 1 October 2019).

Sample Availability: Samples of the compounds and biological material used in this study are not available from the authors.

(C) 2019 by the authors. Licensee MDPI, Basel, Switzerland. This article is an open access article distributed under the terms and conditions of the Creative Commons Attribution (CC BY) license (http://creativecommons.org/licenses/by/4.0/). 